\title{
Factors in the sociocultural environment of child labourers: a study in a small scale leather goods industry in Calcutta
}

\author{
Sampa Mitra
}

\begin{abstract}
Objectives-During a study of the occupational health of the child workers in several small leather workshops, investigations were also made of the sociocultural factors that made it necessary for the children, aged between 7 and 14 years, to work. The psychosocial effects of the same factors were also investigated.

Methods-Personal interviews were carried out with a prepared questionaire, and the findings were compared between the working children and a control group of the same number of non-working children from the neighbourhood, matched for age, sex, and religion.

Results-It was found that the foremost cause of taking up employment by the children was poverty. The overall effects found were deprivation of education and lowering of aspirations, that indicated a blunting of mental faculties.

Conclusion-Prolonged, monotonous work in childhood that precludes education and healthy recreation, is harmful to the children.
\end{abstract}

(Occup Environ Med 1994;51:822-825)

Keywords: child labour; economic deprivation; sociocultural effects

Child labour is widespread all over the world, specially in the developing countries. Children, obliged to work for subsistence, besides being subjected to the general and specific health hazards in different occupational environments, are deprived of many of the things essential and integral to their normal development. These are, education, play and recreation, socialisation with friends at school, company of parents and siblings at home, and on the whole a carefree and joyous existence full of dreams and hopes.

The deprivations are bound to affect them, although the outcomes may not be apparent immediately in measurable ways. Acting insidiously, they may create potential shortfalls in mental and social development of such children that may have future personal and social repercussions.

According to the agreed definition of health, mental and social factors are inextricably related to physical health and contribute to the total health. It is therefore important to attempt to understand the social, economic, psychological, and cultural background factors as much as possible while undertaking a study of the health conditions of any group in the community-such as the working children.

In an earlier communication, I summarised my findings on the health conditions of child labourers in a small scale leather industry in Calcutta, ${ }^{1}$ in comparison with those of a suitable control group. The present paper presents findings on their overall life situations, focusing mainly on sociocultural factors found during the earlier study.

Materials and methods

The field for the study was a big slum area inhabited almost entirely by Urdu speaking Muslims. The area, located in central Calcutta, had a large number of small workshops that manufactured hand made leather goods, mainly shoes and slippers. The method of the study has already been described in detail in the previous communication. ${ }^{\prime}$ In brief, 40 working boys between 7 and 14 years old, attached to the leather workshops of the slum area, were studied. Forty non-working boys who lived in the same slum area and were of the same age range and social group (linguistic, religious, and cultural) were simultaneously studied as controls. Interviews with these children were carried out with a prepared schedule. A clinical examination was also made of each of them. It should be mentioned that it was a big task motivating the shop owners to cooperate in the study. Although some of them agreed finally, which made the study feasible, elements of suspicion and some hostility were always perceptible in them during the study.

\section{Results}

AGE DISTRIBUTION OF THE CHILD WORKERS About $52.5 \%$ of the child workers were 7 to 10 years old and $47 \cdot 5 \%$ were $11-14$. On the whole, most $(40 \%)$ were between 9 and 10 years of age.

\section{WORKING HOURS}

Usually, the work started at 900 (range $800-1000)$ am and continued until 1000 (range 900-1100) pm. During a good business season, work continued even until midnight. Table 1 shows that $55 \%$ of the children worked for 13-14 hours a day and in all, $85 \%$ worked for more than 10 hours a day. A few children $(5 \%)$ worked on a part time basis 
Table 1 Distribution of the 40 working children by total working hours/day

\begin{tabular}{lrl}
\hline Working hours/day & \multicolumn{2}{c}{ Children $(n(\%))$} \\
\hline $5-7+$ & 2 & $(5)$ \\
$8-10+$ & 4 & $(10)$ \\
$11-12+$ & 9 & $(22 \cdot 5)$ \\
$13-14+$ & 22 & $(55)$ \\
$15-17+$ & 3 & $(7 \cdot 5)$ \\
\hline
\end{tabular}

Table 2 Distribution of children in the study $(n=40)$ and control $(n=40)$ groups by levels of education

\begin{tabular}{lccccc}
\hline Levels of education & $\begin{array}{l}\text { Study of } \\
\text { child workers } \\
(n(\%))\end{array}$ & $\begin{array}{l}\text { Controls } \\
(n(\%))\end{array}$ \\
\hline $\begin{array}{l}\text { Illiterate (no schooling) } \\
\begin{array}{l}\text { Received some schooling } \\
\text { but discontinued }\end{array}\end{array}$ & 27 & $(67 \cdot 5)$ & 6 & $(15)$ \\
\begin{tabular}{l} 
Continuing study in school \\
\hline
\end{tabular} & 7 & $(17 \cdot 5)$ & $\overline{34}$ & $\overline{(85)}$ \\
\hline
\end{tabular}

(5-7 hours a day). Sunday was the usual holiday. The shops were closed during the major Islamic festivals such as "Id".

\section{EDUCATION}

There was a considerable difference between the education of the study and control groups (table 2). It is evident from table 2 that $85 \%$ of the working children were not going to school, whereas $85 \%$ of the non-working children were going to school regularly although they belonged to the same sociocultural group and had the same living environment. Perhaps this is one of the greatest deprivations the child workers have. It is to be noted, however, that $15 \%$ of the working children (those employed on a part time basis) went to school.

REASONS FOR NON-ATTENDANCE AT SCHOOL BY WORKING CHILDREN

Familial compulsion for financial reasons constituted the main reason for the non-schooling of about $41 \%$ of the child workers. The child workers gave no reply to this question in 35\% of cases. Either they had not thought about it at all or were too shy to speak about it. About $24 \%$ stated that they did not like going to school.

\section{INTELLIGENCE}

A subjective assessment of the level of intelligence of the children was attempted during the interview, by their quickness of understanding, promptness and quality of response, and general alertness. Conventional intelligence tests, with standard tools, were initially planned to be used for this purpose. But during the study, it was considered that the necessary solitude, cooperation, and time essential for performing those types of tests, were not possible in the relatively uncongenial environment of the leather workshops. I then decided that it was feasible to make some subjective assessment of intelligence, dependent upon the particular situation, even though this might enhance the possibility of bias in the observations. Table 3 shows that the percentage of children with higher than average intelligence of the study group was of the same order or even greater than that of the control group.

\section{REASONS FOR ECONOMIC ACTIVITY BY THE CHILD WORKERS}

Table 4 shows that $50 \%$ of the children came to work primarily for financial reason-that is, to support their families by earning money. But for $30 \%$ of the working children, the primary intention was, as stated by them, to learn some occupational skill, particularly when the opportunity was easily available in the local leather workshops.

\section{PARENTS}

\section{Parents' education}

It was found that the prevalence of illiteracy was greater among the parents of the working children (although the difference was not significant) than in the parents of the control group.

\section{Fathers' occupation}

An almost identical distribution of occupations was found in the two groups (table 5). Table 5 shows that about $80 \%$ of the fathers of both the groups of children were somehow employed. I do not know whether the remaining $20 \%$ of the fathers were employed or not, as no information about this was obtained from the children in either group.

\section{SIBLING DEATHS IN FAMILY}

A spectacular difference was found in the percentage of children among the two groups who reported the death of at least one of their siblings (table 6).

\section{ASPIRATIONS OF THE CHILDREN}

The question put to the children was-"What do you want to be in life?". The proportion of children undecided on this issue was greater in the control group (65\%) than in the study group $(35 \%)$. Of the working children $35 \%$ expressed different sorts of aspirations, most of which were based on self employment, independent of formal education (electrician, mechanic, shop-owner, owner of a leather workshop, etc). The non-working children who responded positively to this question

Table 4 Reasons for economic activity by the 40 child workers

\begin{tabular}{ll}
\hline Reasons & \multicolumn{2}{c}{ Children } \\
$n$ & \multicolumn{1}{c}{$(\%)$} \\
\hline Financial reason & $20(50)$ \\
To learn a particular vocational skill & $12(30)$ \\
No reply & $8(20)$ \\
\hline
\end{tabular}

\begin{tabular}{lll} 
in the study $(n=40)$ & and control $(n=40)$ & groups \\
\hline & Study of & \\
child workers & Controls \\
Degree of intelligence & $(\%)$ & $(\%)$ \\
\hline Higher than average & 38 & 28 \\
Average & 40 & 58 \\
Poor & 22 & 14 \\
\hline
\end{tabular}


Table 5 Distribution of fathers' occupation of the 40 study and 40 control children studies

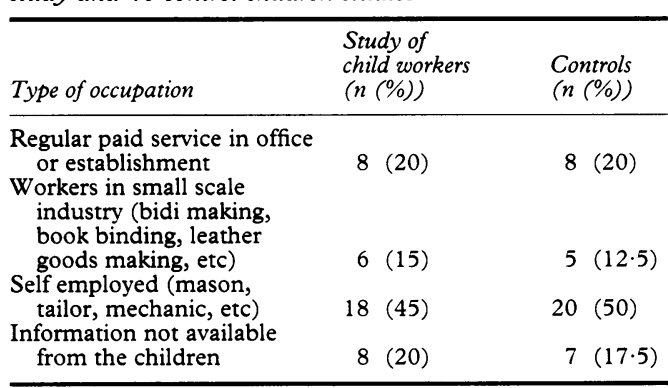

(35\%) mostly had aspirations that were service oriented and based on higher education (doctor, engineer, police, military personnel, high ranking officer, etc). It is to be noted that $30 \%$ of the working children wished only to continue as a leather worker-doing the same job throughout their lives.

DIET

Constituents of the daily diets were mostly similar in the two groups, except some differences in consumption of meat or fish and the number of meals a day. The usual breakfast for both the groups consisted of chapati and vegetable curry. In some cases, left over rice, bread, or cheap snacks from neighbourhood shops were taken for breakfast. Lunch or dinner usually consisted of rice or chapati and vegetable curry, occasionally with lentils. The meat commonly eaten was beef. In the study group, about $52.5 \%$ of children could not tell the usual frequency of their consumption of meat or fish in the diet, or could not even remember taking meat or fish in the recent past. In the control group, only $25 \%$ of children's answers were of a similar nature. The rest reported having meat or fish at least two or three times a week. About $47.5 \%$ of the working children did not usually take any refreshments in the afternoon. Among the non-working children, only $17.5 \%$ were in this category. These differences between the two groups, in the consumption of meat and fish and the number of meals a day, were significant.

TREATMENT OF CHILDREN BY THE SHOP OWNERS OR ADULT COLLEAGUES

One of the misfortunes of child workers, reported in the scientific literature ${ }^{23}$ is physical abuse from the employer or some other adult employees, mostly for enforcing obedience. None of the child workers interviewed in this study reported any adverse treatment of this nature. Also, none of them bore any apparent marks of gross physical punishment during the clinical examination.

\section{PSYCHOLOGICAL AND EMOTIONAL STATE OF} THE CHILD LABOURERS

In general, the working children in the study group did not seem to have any major emotional trauma as judged during the interviews. They were residents of the same slum area in which the workshops were located and where almost all the shop owners also lived.
Table 6 History of sibling death in the 40 study and 40 control children

\begin{tabular}{llll}
\hline $\begin{array}{l}\text { Study } \\
\text { (child workers (n (\%)) }\end{array}$ & $\begin{array}{l}\text { Control } \\
(n(\%))\end{array}$ & $\chi^{2}$ & P-value \\
\hline $26(65)$ & $10(25)$ & 12.94 & $<0.001$ \\
\hline
\end{tabular}

Moreover, most of them lived with their own families - a place to go back at night and during any serious difficulties. In some cases, the shop owners were even related to them, and in this particularly fortunate circumstance the child labourers seemed in general to be happy and content.

\section{Discussion}

In this study, all the children in the study and control groups were residents of a large slum area in Calcutta. The 40 boys in the study (aged from 7 to 14 years) worked in the small scale leather workshops in the slum area. The control group comprised 40 non-working boys within the same age range. All the children lived in the single room slum dwellings, and shared common water and sanitation facilities, and all were Urdu speaking Muslims. So, there were hardly any differences between the two groups in religion, culture, social identity, and living environment. The educational level of the parents and the nature of the fathers' occupations also did not differ much between the two groups.

The greatest perceptible social deprivation, which the working children were subjected to, was lack of general education. About $85 \%$ of the child workers were found not to go to school, whereas $85 \%$ of the non-working children did go to school. When asked about the reason for their non-attendance at school, $35 \%$ of the working children did not give any answer to this question. Probably, they had never thought about it or were too shy to speak on this issue. About $24 \%$ said that they did not like going to school. Most (41\%) pointed out that they had to undertake remunerative work because of familial compulsion for economic reasons. Needless to say the prolonged continuous work schedule of the leather shops (extending over 10-14 hours a day (table 1)) did not permit the working children to attend school simultaneously. The working children who were continuing their studies at school $(15 \%)$ were part time workers in the leather workshops.

Assessment of intelligence of the children under study by conventional intelligence tests with standard tools could not be undertaken in the relatively uncongenial environment of the leather workshops, although this was originally included in the schedule. I subjectively assessed intelligence during the interview with the children by their quickness of understanding, promptness and quality of response, and general alertness. The result showed (table 3 ) that the working children were of similar intelligence to the non-working children.

The working children did not seem to have any major emotional setback, nor did any of 
them bear marks of severe physical punishment. As they were residents of the same slum area in which the workshops were situated, they had been working in a familiar environment, earning something ${ }^{1}$ in most cases, and seemed to be contented. The slow acting physical effects ${ }^{1}$ and the social deprivations did not seem to be felt by the working children during the study. A significant difference was found in the number of children who gave a history of sibling death in the two groups. Although $65 \%$ of the working children reported death of at least one of his siblings in childhood, $25 \%$ of the non-working children reported the same. Given the very similar environmental conditions and cultural characteristics (religion, language, parents' education, etc) pertaining to both the groups, this significant difference may reasonably be attributed to the remaining major determinant of child death, ${ }^{4}$ a relatively unobvious discrepancy in the economic conditions of the two groups.

Considerable differences found in the daily diet of the two groups, particularly consumption of meat or fish and the number of meals a day, also speak for the inequality in the economic conditions of the two groups. At interview, $50 \%$ of the child labourers plainly admitted that economic necessity was the main driving force for their taking up employment. Thus, it seems that both direct and indirect evidence point to poverty as the foremost reason for child labour in this particular situation. Poverty, as the prime motivating force behind child labour, has also been reported elsewhere. ${ }^{5}$ For $30 \%$ of the child workers, the economic compulsion acted in an indirect way. In these cases, economic activity had been undertaken either with the objective to learn the particular job as a prospective livelihood or as an alternative to schooling which was not feasible. As there are no free schools in the neighbourhood, to send children to schools was beyond the means of some of the parents. So, as a second choice, the children had been sent to remunerative work in the leather workshops at least to be kept busy with some gainful occupation. For some other children of the same group (30\%) the reason for their economic activity seemed to be their preference for learning a particular job skill rather than the delayed and doubtful prospects of school education. It seemed to me that the presence of the leather workshops in the slum area might have influenced the attitude of the parents to some extent in this respect. The remaining $20 \%$ of the child workers did not give any specific reply to the reason for going to work. But, whatever the motivating force compelling the children to take up work at an early age, the effect was equally damaging for the working childrenthat is, deprivation from a whole normal childhood that included schooling and education.

It was found that about $30 \%$ of the child workers had no other aspirations than to continue in the same work of making leather goods throughout their lives. Usually children have a natural inclination to fantasy and imagination and always dream of a happy future. So, it might be that this group of working children $(30 \%)$ who showed blunting of aspirations, had either attained an early mental maturity, or had their imaginative minds crippled by their routine work in the workshops that was dull, monotonous, and extended over long hours (table 1). It seemed to me that the interaction of the prolonged, monotonous work in the leather workshops, combined with lack of education and proper childhood recreations had begun to affect their mental faculties of hope and imagination that come naturally to a child. A survey of publications on the effect on the mental faculties of children engaged in uninterrupted, stereotyped occupational work showed similar findings by other authors. ${ }^{67}$

I am deeply indebted to Dr B B Chatterjee, Ex-Professor and head of the Department of Occupational Health, All India Institute of Hygiene and Public Health, Calcutta, for his valuable advice and sincere help throughout this study. Gratitude is also due to Dr S P Mukhopadhyay, Professor and Head of the Department of Social and Preventive Medicine, All India Institute of Hygiene and Public Health, Calcutta, for his active encouragement and cooperation during this study. I gratefully acknowledge Dr D P Mitra for his help, especially during the field work, which made the study feasible.

1 Mitra S. A study of the health conditions of child workers in a small scale leather industry in Calcutta. $\mathrm{Br} \mathcal{F}$ Ind $\mathrm{Med}$ 1993;50:938-40.

2 Dingwaney M. Children of darkness. Rural labour cell New Delhi 1988;41-3, 50:117.

3 Pitt, David C. In: Naidu US, Kapadia KR, eds. Child labour and health. Bombay: Tata Institute of Social Sciences, 1985, 18.

4 Last JM, ed. Maxcy Rosenau public health and preventive medicine, 12th ed. East Norwalk, CT: Appleton Century Crofts, 1986:84-7, 1722.

5 Abeysinghe D. Country report on Sri Lanka. Proceedings of the 2nd Asian Regional Conference on child abuse and neglect-prevention and protection of working children and neglect-prevention and protection of working children and abandoned

6 Dogramaci I. In: Shah PM ed. Child labour: an overview. child labour: a threat to health and development. Geneva: Defence for Children International, 1985:10.

7 Mendelievich E, ed. Children at work. Geneva: International Labour Organisation 1980:48. 